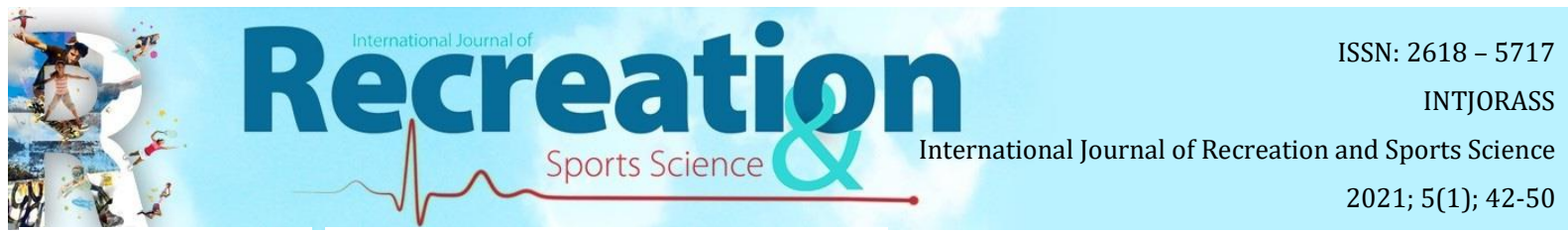

Research Article - https://doi.org/10.46463/ijrss.978762

\title{
Motivation to Participate in Exercise in Regular Recreational Exercise
}

\author{
Tebessüm AYYILDIZ DURHAN ${ }^{1} \quad$ Ali Selman ÖZDEMIR ${ }^{2}$ \\ Suat KARAKÜÇÜK
}

\begin{abstract}
The purpose of this study is to determine the levels of motivation of individuals participating in regular recreational exercise to exercise and to examine the direction of certain variables. While the study group of the research was composed of 370 university students, the criterion sampling method was used as the sampling method. In the research, Mullen et al. (Exercise Behavioral Regulation Scale-2", which was developed by Ersöz (2011), which was developed by Markland and Tobin (2004) and was renamed "Behavioral Regulation Scale in Exercise Scale-2". In the analysis of the data, descriptive statistics, independent sample T test, oneway analysis of variance ANOVA test and post hoc tests were used for intra-group comparisons. When the total behavioral regulation scores were examined, the participants who showed the mean scores $(34,11 \pm 9,58)$ received the highest score in the internal regulation sub-dimension $(19,83 \pm 6,27)$, while they showed below average scores in the motivation dimension $(3,23 \pm 3,74)$. As a result of the research, it can be said that regular recreational exercise and certain variables change behavioral regulation in exercise.
\end{abstract}

Keywords: Motivation, regular, recreational exercise

\section{Düzenli Rekreasyonel Egzersizde Egzersize Katılma Motivasyonu}

$\ddot{\boldsymbol{O}_{z}}$

Bu çalışmanın amacı, düzenli rekreasyonel egzersize katılan bireylerin egzersiz yapma motivasyon düzeylerini belirlemek ve belirli değişkenlerin ne doğrultuda farklılaştırdığını incelemektir. Araştırmanın çalışma grubunu 370 üniversite öğrencisi oluştururken, örneklem yöntemi olarak ölçüt örnekleme yöntemi kullanılmıştır. Araştırmada, veri toplama aracı demografik veri formuna ek olarak Mullan, Markland ve Ingledew (1997) tarafından geliştirilen ve Markland ve Tobin (2004) tarafından revize edilen, Ersöz (2011) tarafından Türkçe'ye uyarlanan "Egzersizde Davranış Düzenlemeleri Ölçeği-2" kullanılmıştır. Verilerin analizinde betimsel istatistikler, bağımsız örneklem T testi, tek yönlü varyans analizi ANOVA testi, grup içi karşılaştırmalarda post hoc testleri kullanılmıştır. Toplam davranışsal düzenleme puanları incelendiğinde, ortalama puanları $(34,11 \pm$ $9,58)$ gösteren katılımcılar en yüksek puanı içsel düzenleme alt boyutunda $(19,83 \pm 6,27)$ alırken, amotivasyon boyutundaki puanlar en düşük alt boyut puanını oluşturmaktadır $(3,23 \pm 3,74)$. Araştırma sonucunda düzenli rekreasyonel egzersizin ve belirli değişkenlerin egzersizde davranışsal düzenlemeyi değiştirdiği söylenebilir.

Anahtar Kelimeler: Motivasyon, düzenleme, rekreasyonel egzersiz

${ }^{1}$ Gazi University, Faculty of Sports Sciences, Ankara-TURKEY, tebessum@ gazi.edu.tr https://orcid.org/0000-0003-2747$\underline{6933}$

${ }^{2}$ İstanbul Aydın University, Faculty of Sports Sciences, Istanbul-Turkey, ozdemiraliselman@gmail.com https://orcid.org/0000-0003-1736-7602

${ }^{3}$ Gazi University, Faculty of Sports Sciences, Ankara-TURKEY, ksuat@gazi.edu.tr https://orcid.org/0000-0001-91447307 


\section{INTRODUCTION}

Participation in exercise has many positive effects on physical, metabolic and psychological health, and there are many factors that affect people's orientation to exercise. One of these factors is motivation (Eraslan, Bezci and Altınkök, 2016). The main meaning of motivation is that a person is willing to do something. Motivation has a lot to do with arousal, excitement, feedback, and attention. Although there are many different definitions of motivation, the common feature of all of them is that it is an internal state or an internal desire as it is sometimes defined, as a result of which it activates or gives power and directs it. The presence of an internal state that motivates the behavior, the presence of a desire that gives direction and power to this being, and the effect of this desire on the intensity and direction of the behavior (Erdem, 2008). The level of motivation in an individual has a direct effect on many features (Güngör and Kurtipek, 2020). The concept of motive, which is any force, motive (TDK, 2005) that causes, sustains and directs the behavior consciously or unconsciously is used as a synonym for the word motivation in the literature.

To be motivated means to be moved to do something. A person who feels no impetus or inspiration to act is thus characterized as unmotivated, whereas someone who is energized or activated toward an end is considered motivated. Most everyone who works or plays with others is, accordingly, concerned with motivation, facing the question of how much motivation those others, or oneself, has for a task, and practitioners of all types face the perennial task of fostering more versus less motivation in those around them (Ryan and Deci, 2000a). Motivation concerns energy, direction, persistence and equifinality-all aspects of activation and intention. Motivation has been a central and perennial issue in the field of psychology, for it is at the core of biological, cognitive, and social regulation (Ryan and Deci, 2000b).

Motivation is closely related to the actions of the individual with his / her own free will. When it comes to the success orientation of the individual, it plays an important key role in this matter (Kurtipek, Güngör and Yenel,
2018). In this context, there are many theories put forward to make sense of the foundations of motivation. One of the most prominent of these theories in the literature is the "selfdetermination theory", also known as free will (Deci and Ryan, 1985). Researchers studying self-determination theory set out from the concept of motive to express regulatory processes in exercise (Ingledew and Markland, 2008). According to this theory, the direction of behavior is associated with relational links between stimuli (internal or external) and responses. The right to self-determination is the quality of human functionality. The experience of choice, in other words, the experience of the inner perceived causality focus. It is an integral part of intrinsically motivated behavior and is also evidence in some extrinsically motivated behavior (Deci and Ryan, 1985).

This theory claims that the activities carried out by self-determination stem from the belief that the activity is not interested in the activity or that the activity is inherently valuable (Carver and Scheier, 1998). According to the free will / self determination theory; the underlying causes of motivation can be found in two categories, internal and external. For these reasons, the individual develops a control focus. If the motivation is internal, the locus of control is internal. If it is external, the locus of control is external. Although behavior occurs in both locus of control, the psychological mechanisms that control behavior are different from each other. As a result, the strength and continuity of behavior will differ in these two situations (Erdem, 2008). Behavioral regulation can be demonstrated with internal and external self-determination. Behavioral modifications are important psychometric features of exercise participation (Figure 1). The self-regulation of brain activity in humans through its way represents a fascinating and promising methodology in behavioral neuroscience and psychophysiology (Elbert et al., 1984).

Self regulation; It is to interpret as a dynamic motivational system such as setting goals, developing and implementing strategies to achieve these goals, evaluating progress and revising goals and strategies accordingly. Self- 
regulation also related to the management of emotional responses, which are seen as vital elements of the motivational system and are thought to be complexly linked to cognitive processes (Ridder and Wit, 2006). From the exercise participation perspective, behavioral adjustments are directly linked to reasons for participation. Challenge, health desire for fitness, stress management, appearance anxiety, social relationships bring different behavioral regulations. While appearance anxiety is matched with external regulation, factors such as stress management are identified with internal management (Ingledew and Markland, 2009).

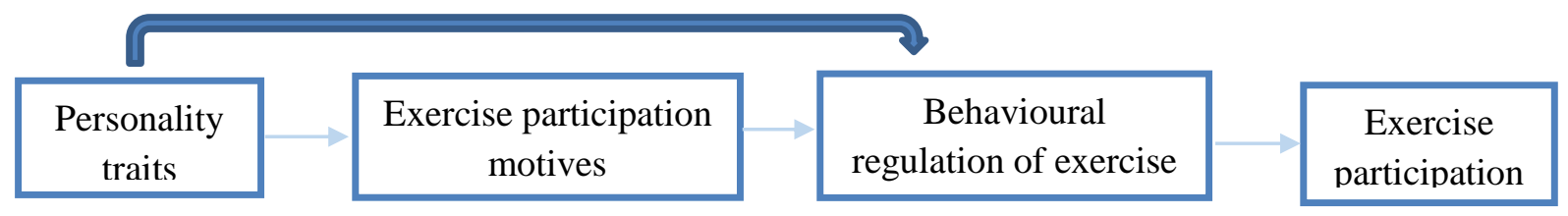

Figure1. General motivational model of exercise participation. (Source: Ingledew and Markland, 2008).

Within the scope of the present study, which aims to investigate behavioral regulations in exercise and the internal and external regulations that constitute its infrastructure, within the sample group, it is aimed to reveal the level of incentive of individuals who

\section{METHOD}

\section{Participants}

While the study group of the research consisted of 370 university students doing regular recreational exercise, the criterion sampling method was used based on the fact that the sample was formed from people with the specified qualifications related to the problem. The majority of men $(82.7 \%)$ who regularly exercise recreational exercise. How certain variables change the motivation to participate in exercise will be examined within the scope of the research. The methods and methods applied in the research are given below.

study at Gazi University and Bulent Ecevit University, who regularly perform recreational exercise, have been training for 1 year or less than 1 year $(38.1 \%)$, currently training 3 times a week $(37 \%, 0)$, it is seen that it consisted of participants $(60.0 \%)$ who had previously been interested in a sport. Descriptive statistics are given in Table 1.

Table 1. Descriptive statistics of participants

\begin{tabular}{llll}
\hline \multirow{2}{*}{ Gender } & \multicolumn{3}{c}{$\mathrm{N}=(370)$} \\
\cline { 2 - 4 } & Variable & $\mathrm{f}$ & $\%$ \\
\hline \multirow{2}{*}{ Duration of exercise } & Female & 64 & 17,3 \\
\cline { 2 - 4 } & Male & 306 & 82,7 \\
\cline { 2 - 4 } & 1 year and lower & 141 & 38,1 \\
\cline { 2 - 4 } & Between 2-3 year & 84 & 22,7 \\
\cline { 2 - 4 } & Between 4-5 year & 43 & 11,6 \\
\cline { 2 - 4 } & Between 6-7 year & 31 & 8,4 \\
\cline { 2 - 4 } & Between 8-9 year & 25 & 6,8 \\
\cline { 2 - 4 } Weekly exercise & Between 10-11 year & 46 & 12,4 \\
& 1 time a week & 27 & 7,3 \\
\cline { 2 - 4 } & 2 times & 63 & 17,0 \\
\cline { 2 - 4 } & 3 times & 68 & 37,0 \\
\cline { 2 - 4 } & 4 times & 37 & 18,4 \\
\cline { 2 - 4 } & 5 times & 222 & 10,0 \\
\cline { 2 - 4 } & 6 times and more & 148,3 \\
\hline Formerly doing sports & Yes & 38,0 \\
\cline { 2 - 4 } & No & 60,0 \\
\hline
\end{tabular}




\section{Measurement tool}

In addition to the data collection tool demographic data form, "Behavioral Regulations in Exercise Scale-2", which is developed by Mullan, Markland and Ingledew (1997) and revised by Markland and Tobin (2004) and adaptated to Turkish by Ersöz (2011) was used.

Behavioral Regulations Scale in Exercise-2; "Behavioural Regulations in Exercise Questionnaire-2 (BREQ-2)", was used to determine the motivational orientation of individuals who exercise within the scope of Self-Determination Theory. "Behavioral

\section{Analyses}

Since it was determined that the data showed a normal distribution, parametric tests were applied, descriptive statistics, independent sample $t$ test, one-way analysis of variance ANOVA test, and Tukey test were used for in-

\section{Results}

The tables regarding the findings obtained as a result of the analyzes made in the research are given below.
Regulations Scale in Exercise (BREQ)", Mullan, Markland and Ingeledew (1997) and was revised by Markland and Tobin (2004) and named as "Behavioral Regulations in Exercise Scale-2". BREQ-2 is an extension of BRIES and includes the non-motivation subscale (2002). Its validity and reliability were tested by Mullan and Markland (2004). Ersöz (2011) carried out the validity and reliability study by adapting it to Turkish. BRS-2 is a 5-point Likert-type scale with a score between $0-4$, consisting of "absolutely not correct", "sometimes correct" and "absolutely correct".

group comparisons. In this study, the internal consistency coefficient for the Behavioral Regulations in Exercise Scale-2 scale was determined as .73.

Table 2. Arithmetic mean and standard deviation values for measurement tool

\begin{tabular}{lllll}
\hline & \multicolumn{3}{c}{$\mathrm{N}=(370)$} \\
\cline { 2 - 5 } & Min & Max. & $\bar{x}$ & sd \\
\hline Behaviour regulation in exercise & 0,00 & 68,00 & 34,11 & 9,58 \\
\hline Intrinsic Regulation & 0,00 & 28,00 & 19,83 & 6,27 \\
\hline Inrojected Regulation & 0,00 & 16,00 & 7,71 & 4,10 \\
\hline External Regulation & 0,00 & 16,00 & 3,33 & 3,44 \\
\hline Amotivation & 0,00 & 16,00 & 3,23 & 3,74 \\
\hline
\end{tabular}

When the total behavioral regulation scores were examined, the participants who showed the mean scores $(34,11 \pm 9,58)$ received the highest score in the intrinsic regulation sub- dimension $(19,83 \pm 6,27)$, while they showed below average scores in the amotivation subdimension $(3,23 \pm 3,74)$. 
Ayyıldız Durhan T., Özdemir, A. S. \& Karaküçük, S. (2021). Motivation to Participate in Exercise in Regular Recreational Exercise. International Journal of Recreation and Sport Science, 5 (1); 42-50.

Table 3. Comparison of measurement tool and its sub-dimensions with gender variable

\begin{tabular}{|c|c|c|c|c|c|c|}
\hline & Gender & $\mathrm{N}$ & $\bar{x}$ & ss & $\mathrm{t}$ & $\mathrm{p}$ \\
\hline \multirow[t]{2}{*}{ Behaviour regulation in exercise } & Female & 64 & 33,68 & 10,67 & \multirow[t]{2}{*}{$-0,393$} & \multirow[t]{2}{*}{0,694} \\
\hline & Male & 306 & 34,20 & 9,35 & & \\
\hline \multirow[t]{2}{*}{ Intrinsic Regulation } & Female & 64 & 17,32 & 7,08 & \multirow[t]{2}{*}{$-3,572$} & \multirow[t]{2}{*}{$0,000^{*}$} \\
\hline & Male & 306 & 20,35 & 5,96 & & \\
\hline \multirow[t]{2}{*}{ Inrojected Regulation } & Female & 64 & 7,64 & 3,94 & \multirow[t]{2}{*}{$-0,150$} & \multirow[t]{2}{*}{0,881} \\
\hline & Male & 306 & 7,72 & 4,14 & & \\
\hline \multirow[t]{2}{*}{ External Regulation } & Female & 64 & 4,23 & 4,00 & \multirow[t]{2}{*}{2,315} & \multirow[t]{2}{*}{$0,021 *$} \\
\hline & Male & 306 & 3,14 & 3,29 & & \\
\hline \multirow[t]{2}{*}{ Amotivation } & Female & 64 & 4,48 & 3,89 & \multirow[t]{2}{*}{2,959} & \multirow[t]{2}{*}{$0,003 *$} \\
\hline & Male & 306 & 2,97 & 3,66 & & \\
\hline
\end{tabular}

According to the $\mathrm{T}$ test results between the gender variable of the participants and the Behavioral Regulations in Exercise Scale-2. Male participants have hihger levels than female participants in intrinsic regulation $(\mathrm{t}=$ -
$3.572 ; \mathrm{p}=0.05)(\overline{\mathrm{X}}=20.35 \pm 5.96)$. Also female participants have higher levels in external regulation $(\mathrm{t}=2.315 ; \mathrm{p}=0.05)(\overline{\mathrm{X}}=$ $4.23 \pm 4.00)$, amotivation subdimension $(\mathrm{t}=$ $2.959 ; \mathrm{p}=0.05)(\overline{\mathrm{X}}=4.48 \pm 3.89)$.

Table 4. Comparison of the measurement tool and its sub-dimensions with the number of weekly exercises

\begin{tabular}{|c|c|c|c|c|c|c|}
\hline & Weekly exercise & $\mathrm{n}$ & $\bar{x}$ & ss & $\mathrm{F}$ & $\mathrm{p}$ \\
\hline Behaviour regulation & 1 time a week & 27 & 30,62 & 8,6 & 1,803 & 0,111 \\
\hline \multirow[t]{6}{*}{ in exercise } & 2 times & 63 & 32,07 & 8,36 & & \\
\hline & 3 times & 137 & 34,74 & 9,25 & & \\
\hline & 4 times & 68 & 35,48 & 9,57 & & \\
\hline & 5 times & 37 & 34,13 & 12,62 & & \\
\hline & 6 times per week and more & 38 & 35,23 & 9,36 & & \\
\hline & Total & 370 & 34,11 & 9,58 & & \\
\hline \multirow[t]{7}{*}{ Intrinsic Regulation } & 1 time a week & 27 & 18,88 & 4,44 & 2,646 & $0,023 *$ \\
\hline & 2 times & 63 & $17,92^{\mathrm{d}}$ & 5,05 & & \\
\hline & 3 times & 137 & $19,85^{\mathrm{c}}$ & 6,18 & & \\
\hline & 4 times & 68 & $21,22^{b}$ & 6,06 & & \\
\hline & 5 times & 37 & 19,37 & 8,56 & & \\
\hline & 6 times per week and more & 38 & $21,57^{\mathrm{a}}$ & 6,57 & & \\
\hline & Total & 370 & 19,83 & 6,27 & & \\
\hline \multirow[t]{7}{*}{ Inrojected Regulation } & 1 time a week & 27 & $5,77^{f}$ & 3,67 & 4,273 & $0,001 *$ \\
\hline & 2 times & 63 & $6,47^{\mathrm{e}}$ & 4,07 & & \\
\hline & 3 times & 137 & $7,60^{\mathrm{d}}$ & 3,76 & & \\
\hline & 4 times & 68 & $8,75^{\mathrm{b}}$ & 3,77 & & \\
\hline & 5 times & 37 & $8,67^{c}$ & 4,89 & & \\
\hline & 6 times per week and more & 38 & $8,71^{\mathrm{a}}$ & 4,47 & & \\
\hline & Total & 370 & 7,71 & 4,10 & & \\
\hline \multirow[t]{7}{*}{ External Regulation } & 1 time a week & 27 & 2,96 & 3,29 & 1,304 & 0,261 \\
\hline & 2 times & 63 & 3,90 & 3,52 & & \\
\hline & 3 times & 137 & 3,59 & 3,50 & & \\
\hline & 4 times & 68 & 2,91 & 3,27 & & \\
\hline & 5 times & 37 & 3,37 & 3,68 & & \\
\hline & 6 times per week and more & 38 & 2,42 & 3,17 & & \\
\hline & Total & 370 & 3,33 & 3,44 & & \\
\hline \multirow[t]{7}{*}{ Amotivation } & 1 time a week & 27 & 3,00 & 3,65 & 1,517 & 0,184 \\
\hline & 2 times & 63 & 3,77 & 3,39 & & \\
\hline & 3 times & 137 & 3,69 & 3,96 & & \\
\hline & 4 times & 68 & 2,60 & 3,49 & & \\
\hline & 5 times & 37 & 2,70 & 3,38 & & \\
\hline & 6 times per week and more & 38 & 2,52 & 4,16 & & \\
\hline & Total & 370 & 3,23 & 3,74 & & \\
\hline
\end{tabular}


According to the Anova test findings, a statistically significant difference was determined between the number of exercises performed per week by the participants and the sub-dimensions of intrinsic regulation $(\mathrm{F}=2.646 ; \mathrm{p}=0.05)$ and behaviour regulation $(\mathrm{F}=4.273 ; \mathrm{p}=$ 0.05). According to the results of Tukey tests performed to compare the differences within the group, 6 times a week and more exercises in the sub-dimensions of intrinsic regulation $(\overline{\mathrm{X}}=21.57 \pm 6.57)$ and inrojected regulation $(\overline{\mathrm{X}}=8.71 \pm 4.47)$. It was determined that the participants who demonstrated behavioral regulation level in more positive exercise than other exercise numbers. As the number of exercises decreased, behavioral adjustments in exercise decreased in parallel.

Table 5. Comparison of measurement tool and its sub-dimensions with previous exercise variable

\begin{tabular}{|c|c|c|c|c|c|c|}
\hline & $\begin{array}{l}\text { Previous } \\
\text { exercise }\end{array}$ & $\mathrm{n}$ & $\bar{x}$ & ss & $\mathrm{t}$ & $\mathrm{p}$ \\
\hline \multirow{2}{*}{$\begin{array}{l}\text { Behaviour regulation in } \\
\text { exercise }\end{array}$} & Yes & 222 & 33,31 & 9,89 & \multirow[b]{2}{*}{$-1,977$} & \multirow[b]{2}{*}{$0,049 *$} \\
\hline & No & 148 & 35,31 & 9,00 & & \\
\hline \multirow[t]{2}{*}{ Intrinsic Regulation } & Yes & 222 & 20,41 & 6,24 & \multirow[b]{2}{*}{2,205} & \multirow{2}{*}{$0,028 *$} \\
\hline & No & 148 & 18,95 & 6,22 & & \\
\hline \multirow[t]{2}{*}{ Inrojected Regulation } & Yes & 222 & 7,59 & 4,36 & \multirow[b]{2}{*}{$-0,667$} & \multirow[b]{2}{*}{0,505} \\
\hline & No & 148 & 7,88 & 3,67 & & \\
\hline \multirow[t]{2}{*}{ External Regulation } & Yes & 222 & 2,86 & 3,33 & \multirow[b]{2}{*}{$-3,269$} & \multirow[b]{2}{*}{$0,001 *$} \\
\hline & No & 148 & 4,04 & 3,49 & & \\
\hline \multirow[t]{2}{*}{ Amotivation } & Yes & 222 & 2,44 & 3,39 & \multirow{2}{*}{$-5,184$} & \multirow{2}{*}{$0,000 *$} \\
\hline & No & 148 & 4,43 & 3,93 & & \\
\hline
\end{tabular}


According to the $\mathrm{T}$ test findings performed between the participants' previous exercise status and the behavioral regulation in exercise scale, a statistically significant relationship was found in all sub-dimensions and in the total score, except for the inrojected regulation sub-dimension. Accordingly, the levels are higher of those who have not exercised before than the other group, in total scores $(\mathrm{t}=-1,977$; $\mathrm{p}=0.05)$, external regulation $(\mathrm{t}=-3,269 ; \mathrm{p}=$ $0.05)$, and amotivation subdimensions ( $\mathrm{t}=-$ 5,184; $\mathrm{p}=0.05)$. Meanwhile, significant relationships are revealed in favor of those who have exercised before in in intrinsic regulation sub-dimension $(t=2.205 ; \mathrm{p}=0.05)$.

\section{Discussion and Conclusion}

The findings of the research conducted to determine the motivation to participate in the exercise of the individuals participating in regular recreational exercise showed that they showed the motivation to participate in the exercise in the average values, they obtained the highest score in the internal regulation and the lowest averages in the non-motivation subdimension. It has been determined that variables such as gender, number of exercises per week and previous exercise change behavioral regulations in exercise. Based on the self-determination theory that forms the basis of the current research, Ersöz, Özşaker and Sasur (2016) conducted a similar study examining behavioral regulations in exercise, the findings show that men participate in exercise with more introjection and external behavioral modifications, and girls show lower motivation than boys. In another study, motivation in physical education classes was examined, and it was determined that boys showed higher exercise motivation than girls. The findings of the study indicate that the freewilled behavior of the individual contributes to a more willing participation in physical education lessons and to gain more pleasure from physical education lessons (Ada, 2011).

Research findings in which the relationship between goal orientation, behavioral regulations and psychological needs in exercise were determined, contrary to the current research findings, revealed that female participants participated in the exercise for less external reasons than men (Erşen, 2019). Research findings investigating motivational regulations in exercise and social physical anxiety level in the context of quality of life are also; It revealed that there was no significant relationship between behavioral modifications in gender and exercise, but the averages of males were higher than females. There are also studies stating that gender does not change behavioral regulation in exercise (Ersöz, 2011; Y1ld1z, 2015). Other findings point out that; regular exercise positively affects behavioral regulation by contributing to the psychological and social characteristics of individuals (Güngör, Y1lmaz and İlhan, 2019). In another study conducted with only female participants, no statistically significant difference was found between the scores of the behavioral regulations in exercise subdimensions according to the leisure exercise levels of women (Bekar, Yerlisu Lapa and Demircioğlu, 2019).

On the other hand, it was revealed in another study that exercise frequency and duration changed behavioral regulations in exercise (Y1ldiz, 2015) Rose, Parfitt and Williams (2005) found that participants who exercise regularly had high intrinsic motivation. In an experimental study, it was determined that subjects who decreased their exercise levels increased their extrinsic exercise motivation, while increasing exercise levels increased intrinsic motivation (Ortís et al, 2007). Therefore, it is a statement supported by the literature that regular recreational exercise has the characteristic of being sustainable when the 
intrinsic motivation is provided, considering the behavioral regulations. Studies in which behavioral modifications in exercise are determined to be related to different parameters in external and internal dimensions (Ingledew and Markland, 2008; Günal, 2018; Kolsallayan, 2017; Lim and Wang, 2009; Markland, 2009; Markland and Tobin, 2010; Yağar, 2016; Y1ldırım, 2015) reveal that many factors change exercise motivation.

As a result of the research, it was determined that the frequency of participating in regular recreational exercise participants and their motivation to participate in exercise changes in line with certain variables. Research findings are important in terms of increasing the demand for recreational exercise participation and determining the psychometric properties of the current participants. In the practices to be organized in this direction, the motivation for participation in recreational exercise should be arranged by taking into account the internal and external factors. It is seen that motivation studies to be carried out on different groups are important in increasing the quality and predictability of recreational practices. It is suggested that the studies to be conducted should take into account participant-centered parameters such as behavioral regulations in increasing recreational participation.

\section{REFERENCES}

Ada, E.N. (2011). An examination of the effects of perceived motivational climate and motivation on dispositional flow state in physical education classes. Ege University, Institute of Health Science, $\mathrm{PhD}$ Thesis, İzmir.

Bekar, Ö., Yerlisu Lapa T., Demircioğlu, M. (2019). Fitness merkezlerine devam eden kadınların egzersiz skorlarl, egzersiz yapma nedenleri ve duygu durumlarl arasindaki ilişkinin incelenmesi. 2. Uluslararası Rekreasyon ve Spor Yönetimi Kongresi, 11- 14 Nisan, Muğla.
Carver, C.S., Scheier, M. F. (1998). On the selfregulation of behavior. New York: Cambridge University Press.

Deci, E.L, Ryan, R.M. (1985). Intrinsic motivation and self-determination in human behavior. New York: Plenum.

Elbert, T., Rockstroh, B, Luzenberger, W, Birbaumer, N. (1984). Self-regulation of the brain and behavior. Springer-Verlag Berlin Heidelberg, New York.

Eraslan, M., Bezci, Ş., Altınkök, M. (2016). Theorical assessment of the factors affecting the exercise motivation. Journal of International Sport Sciences, 2(2), 1-10.

Erdem, M. (2008). Development of sport motivation scale at american football players. Ankara University, Institute of Health Science, Master Thesis, Ankara.

Ersöz, G., Özşaker, M., Sasur, S. (2016). A selfdetermination theory approach to motivational orientations, basic needs satisfaction and psychological well-being in exercise. Niğde University Journal of Physical Education and Sport Sciences, 10(2), 306-317.

Ersöz, G. (2011). An examination of exercise motivational orientations, dispositional flow state and social physique anxiety of exercisers in terms of stage of change and physical activity level. Ege University, Institute of Health, PhD Thesis, İzmir.

Erşen, K. (2019). Investigation of the relationship between goal orientation and behavioral regulations and psychological needs in exercise. Afyon Kocatepe University, Institute of Health Science, Master Thesis, Afyonkarahisar.

Günal, A., Demirtürk, F., Arıkan, H., İnal, B. (2018). Exercise Behavior, Smoking Addiction and General Health Status of Nursing and Midwifery Students. HSP, 5(2), 169-178.

Güngör, N.B., Kurtipek, S. (2010). Examining the effect of individual innovation level of students of sports sciences faculty on digital literacy with structural equation model. Journal of Human Sciences, 17(2), 756-767.

Güngör, N.B, Yılmaz, A., İlhan, E.L. (2019). Yaşam Kalitesi Bağlamında Özel Bir Sporcunun Kazanımlari: Ebeveyn Görüşleri Doğrultusunda Bir Durum Çalışması. Ankara Üniversitesi Ĕgitim Bilimleri Fakültesi Özel Eğitim Dergisi, 20(3), 421-443.

Ingledew, D.K., Markland, D. (2008). The role of motives in exercise participation. Psychology and Health, 23(7), 807-828. 
Ingledew, D.K, Markland, D. (2009). Three levels of exercise motivation. Applied Psychology: Health and Well-Being, 1(3), 336-355.doi:10.1111/j.1758 0854.2009.01015.x

Kolsallayan, A. (2017). Effects of the exercise participants' physical appearance perfectionism ve psychological well-being levels on exercise participation motivation. Ege University, Institute of Health, Master Thesis, İzmir.

Kurtipek, S., Güngör, N.B., Yenel, F. (2018). Determination of the Success Orientations and Self-Consciousness Levels of the Students from the Faculty of Sports Science. Journal of Education and Learning, 7(6), 203-211.

Lim, B.S.C., Wang, C.K.J. (2009). Perceived autonomy support, behavioural regulations in physical education and physical activity intention. Psychology of Sport and Exercise, 10, 52-60.

Markland, D., Tobin, V.J. (2010). Need support and behavioural regulations for exercise among exercise referral scheme clients: The mediating role of psychological need satisfaction. Psychology of Sport and Exercise, 11, 91-99.

Markland, D. (2009). The mediating role of behavioural regulations in the relationship between perceived body size discrepancies and physical activity among adult women. Hellenic Journal of Psychology, 2009, 6, 169-182.

Markland, D., Tobin, V. (2004). A modification of the behavioral regulation in exercise questionnaire to include an assessment of amotivation. Journal of Sport and Exercise Psychology,26, 191-196.

Mullan, E., Markland, D., Ingledew, D.K. (1997). A graded conceptualisation of selfdetermination in the regulation of exercise behaviour: Development of a measure using confirmatory factor analytic procedures. Personality and Individual Differences, 23, 745-752.

Ortís, L.C., Maymí, J.N., Feliu, J.C., Vidal, J.M.L., Romero, E.P, Bassets, M.P, Herreros, M.V., Brosa, J.V. (2007). Exercise motivation in university community members: A behavioural intervention. Psicothema, 19(2), 250-255.

Ridder, T.D., Wit, B.F. (2006). (Eds). Selfregulation in Health Behavior. John Wiley \& Sons Inc. USA, 3.

Rose, E.A., Parfitt, G., Williams, S. (2005). Exercise causality orientations, behavioural regulation for exercise.
Psychology of Sport and Exercise, 6, 399414.

Ryan, R.M., Deci, E.D. (2000a). Intrinsic and extrinsic motivations: classic definitions and new directions. Contemporary Educational Psychology, 25, 54-67.

Ryan, R.M, Deci, E.L. (2000b). Self-determination theory and the facilitation of intrinsic motivation, social development, and wellbeing. American Psychologist, 55(1), 6878.

Türk Dil Kurumu, Türkçe sözlük (10. baskı). (2005). Ankara: TDK.

Wilson, P.M., Rodgers, W.M. (2002). Fraser SN, Examining the psychometric properties of the behavioral regulation in exercise questionnaire. Measurement in Physical Education and Exercise Science, 6, 1-21.

Yağar, G. (2016). Investigate the relationship between behavioral regulations in exercise, leisure negotiation strategies and physical activity levels in adults who participate in physical activity. Akdeniz University, Institute of Social Sciences, Master Thesis, Antalya.

Yıldırım, S., Yıldız, A., Koruç, Z. (2015). Relationship between Transformational Leadership and Motivational Regulations in Exercise, Hacettepe Journal of Sport Sciences, 26 (2), 35-43.

Yildiz, A. (2015). The relationship of muscle dysmorphia symptoms with basic psychological needs, passion and motivational orientation among exercise participants. Marmara University, Institute of Health Science, Master Thesis, İstanbul. 